\title{
New perspectives on bias in polar questions
} A study of Hungarian - $e$

\author{
Beáta Gyuris*
}

Research Institute for Linguistics, Hungarian Academy of Sciences, Budapest, Hungary

gyuris.beata@nytud.mta.hu

\begin{abstract}
The aim of this paper is to provide new insights for the analysis of bias in polar questions by showing that the distinction proposed by Sudo (2013) between evidential and epistemic biases leads to an integrated picture of the Hungarian system of polar interrogatives. For the first time, a comprehensive analysis of this system is given here and it is shown how the contributions of certain formal features, such as the interrogative and the negative particles, can be captured independently. This perspective helps to explain restrictions on the occurrences of the different forms of polar interrogatives in Hungarian with respect to a large number of question uses. The paper derives the biases associated with the individual constituents from different sources and makes some proposals on how their impact could be incorporated into a formal model of dialogue.
\end{abstract}

\section{Keywords}

bias - polar interrogative - question act - context - dialogue - Hungarian

* Research for the paper was supported by the Hungarian Research Development Fund (откA) under project NK 100804 (Comprehensive Grammar Resources: Hungarian). I am grateful to Ken Turner (editor) and two anonymous reviewers from IRP, as well as to audiences at LAGB 2014 (Oxford), the University of Venice, RIL HAS (Budapest), and the Hungarian Association for Linguistics (Budapest), where previous versions of this paper were presented, particularly to Hans-Martin Gärtner, László Kálmán, István Kenesei, Manfred Krifka, Enikő Németh T., Péter Rebrus, Péter Siptár, and Yasutada Sudo for discussion, criticism, and suggestions.

(C) BEÁTA GYURIS, 2016 | DOI: 10.1163/18773109-00000003

This is an open access article distributed under the terms of the prevailing CC-BY-NC license at the time of publication. 
In the recent semantics-pragmatics literature there has been an intensive discussion about the interpretation of positive and negative polar interrogatives. Although, as is well-known, classical semantic theories assign the same interpretations to them (cf. Hamblin, 1973; Groenendijk and Stokhof, 1984), in several situations they are not substitutable for each other. This is normally attributed to the fact that at least some polar interrogative structures convey certain predispositions of the speaker concerning the true answer. An utterance turns out to be infelicitous if these predispositions, referred to as biases (cf. Huddleston and Pullum, 2002:1989), conflict with information from the context.

So far, much of the discussion about question bias has concentrated on English. An important ambiguity, present in many other languages as well, was described in Ladd (1981) for English preposed negation polar interrogatives, illustrated in (1):

\section{(1) Isn't there a vegetarian restaurant?}

According to Ladd, sentences like (1) can be used under two different circumstances: i) to ask for confirmation of something the speaker believes to be true, which corresponds to a positive proposition $p$ ('there is a vegetarian restaurant'), and ii) to check a new inference according to which $\neg p$ is true, which contradicts the speaker's previous assumption about the truth of $p$. He accounts for this ambiguity by saying that the negation is outside the proposition whose truth value is inquired about in the first case, and inside the proposition in the second case. Following this terminology, I will refer to the relevant interpretations as outside negation (ON) and inside negation (IN) readings. The distinction is supported by data concerning the distribution of positive and negative polarity items as well as of too and either. In (2), the insertability of too signals that we are dealing with an on interpretation, whereas the insertability of either into (3) is a sign of an IN reading:1

(2) Isn't Jane coming too? [ON]

LADD, 1981:166

1 Cf. Büring and Gunlogson (200o) for other means of marking the ON-IN distinction by the grammar of English and German. 
(3) Isn't Jane coming either? [IN]

LADD, 1981:166

In the discussion of bias in polar interrogatives in the literature, cf. Büring and Gunlogson (2000), van Rooij and Šafářová (2003), Romero and Han (2004), Reese (2007), Farkas and Bruce (2010), and Krifka (2017), positive polar interrogatives are considered to be the most neutral option possible ${ }^{2}$ and the basis of comparison.

In the current paper I want to contribute to the discussion of the types and sources of bias in polar questions and of their formal representations by calling attention to a new type of distinction between two basic positive polar interrogative form types, present in Hungarian. I will argue that the featurebased approach proposed by Sudo (2013) on the basis of English and Japanese data provides a very useful tool for capturing the difference between the contexts where these two form types and their respective negative counterparts can appear. Section 2 below introduces the inventory of form types that can be used to express polar questions in Hungarian. Section 3 discusses Sudo's (2013) proposal for a distinction between evidential and epistemic bias. In Section 4, the relevance of the above distinction is shown for the interpretation of Hungarian polar questions. Section 5 discusses the interpretation of the -e interrogative particle in Hungarian and accounts for its distribution. Section 6 makes a proposal for capturing the interpretation of the negative particle in questions, and its interaction with $-e$. Section 7 summarizes the results of the paper. A short Appendix provides diachronic and comparative evidence for our analysis.

Form types expressing polar questions in Hungarian-overview of the data

\section{1}

\section{Form types expressing positive polar questions}

There are two types of positive polar root interrogative clause types in Hungarian, illustrated in (4)-(5) below. In (4a, b), the ' $/$ ' sign represents a characteristic rise-fall contour, spread out on the section of the sentence that is referred to by É. Kiss (2002) as the predicate part (following the possibly empty topic field), with a peak on the penultimate syllable (Varga, 2010:3). This con-

2 Büring and Gunlogson (2000) note, however, that positive polar interrogatives do not completely lack bias either, to be discussed below. 
tour is the only feature that distinguishes $(4 a, b)$ from string-identical declaratives, illustrated in $(6 a, b) .^{3}(5 a, b)$, where the marker of the interrogative sentence-type is the - $e$ particle attached to the (verbal) predicate, are pronounced, as a default, with an end-falling contour, analogous to the one in declaratives like (6a, b), marked by 'I' here. ${ }^{4}$ In the a) examples, the topic field is empty, in the b) examples, the '" sign marks an intonational phrase boundary between the sentence-initial NPs in the topic field and the rest of the sentence.

(4) a. Esik az esö/\? falls the rain 'Is it raining?'

b. Az esó| esik/?? the rain falls 'Is it raining?'

(5) a. Esik-e az esől? falls-E the rain 'Is it raining?'

b. Az eső $\mid$ esik-el? the rain falls-E 'Is it raining?'

(6) a. Esik az esó|. 'It is raining.'

b. Az esố| esik|. 'It is raining.'

3 Ladd (1996) and Grice, Ladd, and Arvaniti (2000: 150) propose that it is to be analyzed as a $\mathrm{L}^{*} \mathrm{HL} \%$ contour, (a sequence of the $\mathrm{L}^{*}$ pitch accent, $\mathrm{H}$ phrase tone and $\mathrm{L} \%$ boundary tone, the latter being part of the structural description of the contour). Cf. Kornai and Kálmán (1988), Mády and Szalontai (2014) and Varga (2002) for further discussion.

4 Note, importantly, that only -e-interrogatives can occur in syntactically embedded positions (cf. Kenesei 1994). Studying the relation between root and embedded -e-interrogatives and of the (previously unnoticed) fact that subordinate - $e$-interrogative clauses cannot contain a negative partice is beyond the scope of this paper. 
As discussed below, both of (4) and (5) can be used (at least in some dialects) as standard information questions in Hungarian, characterized by presumed ignorance on the part of the speaker and knowledge on the part of the hearer, but they are not equally compatible with certain special question interpretations. In what follows, polar interrogatives marked only intonationally will be referred to as /-interrogatives, and those containing the -e interrogative particle will be referred to as-e-interrogatives.

Readers familiar with the interpretational features of English and German rising declaratives (cf. Gunlogson, 2003; Poschmann, 2008) or Serbo-Croatian non-inverted questions (Rakić, 1984), might assume that the form type that was referred to as /-interrogative above should be analyzed as a declarative bearing a special intonational marking. One argument against this assumption is that whereas rising declaratives are incompatible with negative polarity items (NPIs) (cf. e.g. Gunlogson, 2003: 21; König and Siemund, 2007: 293), Hungarian /-interrogatives are not, as the possibility of inserting the NPI valahol is 'anywhere' (literally meaning 'somewhere too') into (4), as in (7a), shows. ${ }^{5}$ The same NPI is also possible in - $e$-interrogatives, as in $(7 \mathrm{~b})$ :

(7) a. Esik valahol is az esö/??

falls anywhere too the rain

'Is it raining anywhere?'

b. Esik-e valahol is az esö?

'Is it raining anywhere?'

An additional form type in Hungarian, shown in (8), is also string-identical to the corresponding declarative, but here each constituent following the topic field retains its accent (with the exception of the verb, when preceded by a focus), and "the rise-fall can appear at every accented syllable, thus forming a sequence of repeated rise-falls" (Varga, 2010: 4) ${ }^{6}$ The contour is represented here by the insertion of the sign ' $N$ ' after each accented word or word sequence:

5 For a detailed discussion on NPIs in Hungarian, cf. Szabolcsi (2002) and Tóth (1999). Abeillé, Godard, and Marandin (2014) observe that predicates denoting a minimal or a maximal quantity are acceptable in rising declaratives in French. We leave comparison of these French data and their Hungarian counterparts for a later occasion.

6 According to Varga (2010: 4), the repeated rise-falls "keep their boundary tone (since this reflects the falling part of the rising-falling contour) even though they cannot have a pause after them." For further discussion, cf. Kálmán and Nádasdy (1994) and Kálmán (2001). 
(8) Esik/\az eső/ ?

'It is raining?'

As opposed to (4), (8) is incompatible with NPIs, shown in (9):

(9) ${ }^{*}$ Esik/ $/$ valahol is $\wedge$ az esö $/$ ?

An additional difference between (4) and (5) versus (8) is based on compatibility with the pragmatic marker vajon 'I wonder', which Kenesei (1992) and Kálmán (2001) see as being restricted to the interrogative sentence type. (10), adapted from Truckenbrodt (2004), provides an illustration: ${ }^{7}$

(10) A: Have you been in touch with Mary lately?

B: $\quad$ Not at all.

A': Vajon talált-e már állást?

vajon found-E already job.acc

'Has she already found a job, I wonder.'

A": $\quad$ Vajon talált már állást $\bigwedge$ ?

'Has she already found a job, I wonder.'

A"': *Vajon $/$ talált már $/ \backslash$ állást $/$ ?

The tests discussed above indicate that (8) and similar structures are to be considered a declarative form type, to be referred to as the $/$-declarative. In what follows, I will not make any systematic proposal on the interpretation of \-declaratives, which I take to be analyzable along the lines proposed for rising declaratives in English and German in the literature. Their uses will, however, be contrasted to those of the two interrogative sentence types whenever it seems appropriate.

Although the range of uses compatible with (4) or (5) seems to vary across dialects, there are certain general features that apply to all of them. There is a particular range of uses that can only be expressed with the help of -einterrogatives, and another range of uses that can only be expressed with the help of /-interrogatives in all dialects, which could be viewed as two ends of a "scale". The former group includes question acts in specific official situa-

7 Vajon was claimed by Gärtner and Gyuris (2012) to mark that a question is "posed" without necessarily being addressed to anyone (Lyons 1977: 755), and shown to be formally analyzable along the lines proposed by Farkas and Bruce (2010) for oare-interrogatives in Romanian. 
tions, where the purpose of questioning is regulated by law and the relation between the interlocutors is formal. Certain special questions and indirect speech acts, discussed below, can, however, be only encoded with the help of $\bigwedge$-interrogatives. Dialects vary with respect to the cases situated 'in the middle', which includes classical information questions: whereas they can be expressed with the help of $/ \backslash$-interrogatives in all dialects, there is variation as to whether $-e$-interrogatives are also available or even preferred. ${ }^{8}$

The acceptability judgments presented in the rest of the paper are based on a dialect, spoken to the east of Budapest, where information questions without specific restrictions on the situation can be expressed both with /interrogatives and -e-interrogatives, preference going for the former.

It is important to emphasize at this point that the interpretational differences to be discussed here, in spite of being robust (as native speakers admit after being confronted with the relevant data), have not been noticed so far in the literature (cf. Péteri, 2013: 880-881, for example), with the exception of some informal remarks in Fábricz (1981), to be discussed below.

\subsection{Possible uses of the positive form types}

In this section we turn to the informal characterization of the interpretational differences between $/ \mathrm{A}$-and $-e$-interrogatives in Hungarian, comparing them to / -declaratives where necessary, by looking at contexts where they are not equally available to express question acts. The discussion was inspired by observations made in the literature on the use of positive and negative polar as well as alternative questions in English, particularly Bolinger (1978), Büring and Gunlogson (2000), van Rooij and Šafářová (2003), and Biezma (2009), and by the characterization of special questions in Truckenbrodt (2004).

Let us first consider how a neutral information question can be expressed in the dialect under consideration:

(11) [Context: A and s talk long-distance on the phone. S wants to know what the weather is like at A's place and asks:]

a. Esik-e az esö?

falls-E the rain

'Is it raining?'

8 The range of dialects where the $-e$-form is not used to express information questions includes a dialect spoken in Budapest, and dialects spoken in the western part of Hungary (László Kálmán, Péter Rebrus, and Enikő Németh T., p.c.). Dialects spoken in Romania are generally assumed to have a preference towards using the $-e$-form for the latter purpose. A detailed discussion of the dialectal differences will be left for another occasion. 


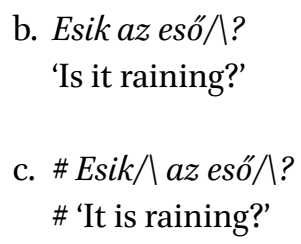

In a biased context, where there is evidence for the positive answer, the acceptability judgments change as illustrated below. ${ }^{9}$

(12) [Context: s's officemate A enters the windowless room with his jacket wet. s asks:]
a. \# Esik-e az eső?
'Is it raining?'
b. \% Esik az eső/ $\wedge$ ?
'Is it raining?'
c. Esik/ az eső/\?
'It is raining?'

The context outlined above illustrates how polar interrogatives can be used to express "questions querying inferences that the speaker draws" (Bolinger, 1978: 88-89), referred to by van Rooij and Šafářvá (2003) as grounding questions (aiming to find out whether some information should be made part of the common ground). ${ }^{10}$ As (12) shows, the best way to formulate a grounding question in Hungarian is to use a /-declarative. Some speakers find /-interrogatives to be acceptable here as well, but $-e$-interrogatives are completely out.

Interrogative sentences are known to be available for the expression of indirect requests and offers/invitations (cf. Searle, 1979). The next example shows which of the three structures under consideration can be used for the purpose of formulating informal requests in Hungarian.

$9 \%$ '\% signals acceptability for a subgroup of speakers. The relevant data have been obtained in the course of informal questioning.

10 Grounding questions are defined by Reese (2007) as "requests by the speaker for evidence that would help him to ground information in the discourse or situational context", in cases where "the information targeted by the grounding question is inconsistent with a prior belief or expectation", and thus the speaker wishes to receive additional evidence for it, or simply a reaffirmation of it (:123). 
(13) [Context: s, carrying heavy luggage, wishes to ask her friend A to open the door for her, so she says the following:]

a. \# Kinyitod-e az ajtót?

pfx.open.2sg-E the door.acc

\# 'Are you going to open the door?'

b. Kinyitod az ajtót/ $/$ ?

'Will you open the door?'

c. \# Kinyitod/\az ajtót/\?

\# 'You are going to open the door?'

As (13b) shows, / -interrogatives can be interpreted as requests, but the corresponding - $e$-interrogative in (13a) can only be interpreted as a genuine request for information. ${ }^{11}$ The $/ \backslash$-declarative in (13c) is similarly out in this context.

The list in (14) illustrates the availability of the three forms for expressing an offer:

(14) [Context: s wishes to offer A some coffee. Therefore she says the following.]

a. Kérsz-e kávét?

want.2sg-E coffee.acc

'Would you like some coffee?'

b. Kérsz kávét/\?

'Would you like some coffee?'

c. \# Kérsz/\kávét/?

\# 'You want coffee?'

11 Note that if instead of the indicative form the conditional form of the verb (kinyitnád 'pfx.open.cond.2sg') is used, both form types are felicitously used to express a request. This probably has to do with the fact that interrogatives containing the conditional form count as conventionalized ways of expressing a request in Hungarian (cf. Szili, 2004). We assume that whenever an interrogative contains an indicative verb form and no auxiliaries expressing ability, possibility or permission, its interpretation as an indirect request is calculated on the sport, on the basis of the principles proposed in Searle (1979). 
Whereas (14c) is definitely out, both (14a) and (14b) are in principle acceptable as ways of expressing an act of offering. These examples are, however, not completely equivalent: whereas (14b) is appropriate in all circumstances, (14a) seems to be restricted to situations where the addresse did not have reason to expect that he would be offered coffee. ${ }^{12}$

Next, it is shown how the forms under consideration can be used to start a conversation:

(15) [Context: Students A and s, who do not know each other, are waiting outside the auditorium to go to the same evening lecture. $s$ wants to initiate a conversation with $\mathrm{A}$, and therefore asks:]

a. \# Elsóéves vagy-e?

first.year be.2sg-E

'Are you a first year student?'

b. Elsóéves vagy/ $\$ ?

'Are you a first year student?'

c. \# Elsöéves/ vagy/?

\# 'You are a first year student?'

As the examples show, only / -interrogatives are available to express a question uttered with the purpose of starting a conversation.

The common property of the contexts illustrated in (12)-(15) above is that the questioner has a preference as to which of the answers is more likely/desirable: they are biased towards one of the possible answers. In the case of (12), the positive answer follows from contextual evidence. The positive answer to (13) corresponds to what the speaker wishes, and in the case of (15), it is the positive answer that takes the speaker closer to her goals, i.e., to lead an interesting conversation (cf. van Rooij and Šafářová 2003 for discussion). With respect to (14), the situation is more complicated. Since it is the positive answer that reflects the speaker's preferences generally associated with offerings, it could be expected, analogously to the case of (13), that only the /-interrogative form should be available. Nevertheless, there is a politeness strategy that gives preference to forms that do not force the speaker's preferences on the addressee,

12 Thus, if $s$ and A previously agreed to meet for coffee, (14a) is out but (14b) is fine. However, if A unexpectedly visits $S$ or they meet for a meal that does not necessarily include coffee, (14a) is also felicitous. 
which favours the (14a) form. (Cf. van Rooij and Šafárová, 2003, for similar examples and Brown and Levinson, 1987: $70 \mathrm{f}$., for general discussion.) A preliminary generalization emerging from the data is thus that $-e$-interrogatives, as opposed to / -interrogatives, are only acceptable in non-biased contexts, or, in other words, that positive -e-interrogatives convey lack of bias on the part of the speaker.

In formal situations, or where answering a question has legal consequences (e.g. marriage ceremony, statement at court, referendum questions), like the one illustrated in (16), only -e-interrogatives are appropriate, across all dialects.

(16) [Context: At a trial, the judge asks the witness:]

a. Ismeri-e a vádlottat?

know.3sg-e the defendant.acc

'Do you know the defendant?'

b. \# Ismeri a vádlottat $\bigwedge$ ?

'Do you know the defendant?'

c. \# Ismeri/\a vádlottat/\?

\# 'You know the defendant?'

If $-e$ indicates the lack of speaker bias, the infelicity of (16a) can be considered a case of blocking: since the /-interrogative form is compatible both with the presence and the lack of bias, but the -e-interrogative form is compatible only with the lack of bias; whenever the speaker wants to make the impression of having no bias, the latter form is chosen.

Contrasts between possible uses of the two interrogative form types were already addressed by Fábricz (1981), but he provides a slightly different characterization of the data: he argues that positive $-e$-interrogatives convey the "uncertainty" of the speaker regarding the answer, and indicate, at the same time, the "curiosity" or the "doubt" of the questioner. He also notes that it is impossible to draw inferences by using the $-e$-form. However, he explains the use of the $/$-interrogative in the following literary example from the 19th century by saying that "in polite questions the familiar tone of $-e$ is disturbing" (: 449):

(17) Megengedik, hogy útitársuk legyek/l? vm.allow.3pl that travel.companion.their be.fut.subj.ssg 'Will you allow me to be your travel companion?' 
This proposal indicates that the author fails to notice that in the case of (17) we are dealing with an indirect request instead of a question. In addition, the classification of $-e$ as marking familiarity does not seem to be the general view: some speakers consider it to mark the style as "elevated".13

The generalization made above, according to which the presence of $-e$ is only allowed in the lack of speaker bias does not appear entirely unproblematic: certain special question types where the speaker is assumed to be certain about the answer (and thus biased towards it) can be expressed with both interrogative forms in Hungarian. These include pedagogical questions (cf. Truckenbrodt, 2004: 322-323), the aim of which is to help the addressee find the answer to a more complex question, monological, or "expository" questions (cf. Austinian expositives, Austin, 1962), which are set up to be addressed and answered later in the discourse by the questioner him/herself (cf. also Brandt et al., 1992: 51; Truckenbrodt, 2004: 325-326), and exam questions (cf: Truckenbrodt, 2004: $327-328$; Searle, 1969), the aim of which is for the questioner to find out whether the addressee knows the answer to the question. (18) illustrates the latter case:

(18) [Context: A teacher starts examining a student by asking the following question.]

a. Magyarországnak van-e tengerpartja?

Hungary.dat be.3sg-E seashore.its

'Does Hungary have a seashore?'

b. Magyarországnak van tengerpartja/

'Does Hungary have a seashore?'

c. \# Magyarországnak/\van/ tengerpartja/\?

'Hungary has a seashore?'

Additionally, it is claimed in the literature (cf. Szikszainé Nagy, 2003, and Péteri, 2011) that $-e$ often marks the rhetoricity of questions, as in the following example:

(19) Csoda-e, ha az ember megbolondul?

miracle-E if the person gets.mad

'Is it a miracle, if a person gets mad?'

SZIKSZAINÉ NAGY, 2003:131

13 L. Kálmán (p.c.). 
Let us assume, following Meibauer (1986: 196), that rhetorical questions constitute indirect assertion of a proposition, the one that the speaker considers to be the correct answer, and which is also identifiable by the hearer. One important source that makes the answer identifiable is that it is based on information from the context. This, however, indicates that $-e$-interrogatives, which were shown above to be infelicitous in contexts that support one of the answers, e.g. (12a), cannot be taken to formally encode rhetorical questions. A similar fact pointing to the same conclusion is that the /-interrogative version of (19) can give rise to the rhetorical question interpretation equally well, but the /-declarative version cannot. We propose an alternative explanation for the availability of a rhetorical question reading of (19) in Section 5 .

This closes our review of the uses of positive polar questions in Hungarian. The following table summarizes the findings made so far concerning the availability of -e-interrogatives, / -interrogatives and / -declaratives for the expression of certain special question types, indicating the numbers of the relevant examples as well (in case any were given).

(20) The expression of certain (special) question types with positive interrogative and $/$-declarative form types in Hungarian

- $e$-interrogative /-interrogative /-declarative

Neutral information
question, (11)
Grounding question, (12)
Indirect request, (13)
Indirect offer, (14)
Conversation starter, (15)
Pedagogical question
Monological question
Exam question, (18)
Rhetorical question, (19)

The fact that pedagogical, monological, exam and rhetorical questions, where the speaker is taken to be familiar with the correct answer, can be expressed

14 The judgments refer to forms containing the indicative form of the verb. 
with -e-interrogatives indicates that the conditions regulating the distribution of the latter cannot be formulated by simply saying that they are incompatible with the speaker's bias, and that a more detailed analysis of the individual cases is required. Before turning to that, in the next section the uses of different types of negative polar questions in Hungarian will be discussed.

\subsection{Form types expressing negative polar questions and their uses}

Hungarian negative /-interrogatives and /-declaratives, illustrated in (21a, b) and (22), respectively, are string-identical to their canonical declarative counterparts, shown in $(23 \mathrm{a}, \mathrm{b})$, where the negative particle nem 'not' is situated in a position immediately preceding the verb. ${ }^{15}$ In the b) examples, the subject noun phrase is situated in the topic field of the sentence.

(21) a. Nem esik az eső/\?

not falls the rain

'Isn't it raining?'

b. $A z$ eső $\mid$ nem esik/।?

the rain not falls

'Isn't it raining?'

(22) $\mathrm{Nem} /$ esik/ az eső/ ?16

'It is not raining?'

(23) a. Nem esik az esó.

'It is not raining.'

b. Az esö| nem esik.

'It is not raining.'

Other things being equal, Hungarian negative / -interrogatives show the IN/ ON ambiguity discussed for English negative polar interrogatives in (2)-(3) above. For example, both sem 'neither' and is 'too' can be inserted into (21a), as shown in (24a) and (25a), respectively. (21b), however, is only compatible with the former, illustrated in $(24 \mathrm{~b})$. If the particle is is followed by preverbal nem, they

\footnotetext{
15 See É. Kiss (2002) for a discussion of the syntax of negative declaratives.

16 The /-declarative counterpart of (21b) would not differ from (21b) in its prosody, since it does not contain any postverbal constituent.
} 
must be merged into sem 'neither' (cf. É. Kiss, 2002: 141-142), which is not satisfied in the case of the ill-formed $(25 b):{ }^{17}, 18,19$

(24) /-interrogatives with IN readings:

a. Nem esik| az esö sem/

not falls the rain either

Isn't it raining, either?'

b. $A z$ eső sem esik/\?

the rain neither falls

'Isn't it raining, either?'

(25) /-interrogative with an on reading:

a. Nem esik az esô is $/$ ?

not falls the rain also

'Isn't it raining, too?'

17 As opposed to obligatorily stressed nem, which forms a phonological word with the subsequent verb, sem is unstressed and forms a phonological word with the word preceding it, which explains why the rise-fall contour is restricted to the postverbal domain in (24a). The declarative sentence string-identical to (25a) can only be used to reject a previous assertion of the form Esik az esó is 'It is raining, too'. There is no similar restriction on the declarative counterparts of (24ab).

18 Another way to test the availability of the IN-reading is to insert negative pronouns and proadverbs beginning with the se-morpheme, like sehol 'nowhere', illustrated in (ia-b) below, which require the presence of a negative particle (cf. É. Kiss, 2002: 136-149), and where thus the negation must be interpreted as part of the proposition questioned.

(i) a. Sehol nem esik az eső/\?

nowhere not falls the rain

'Isn't it raining anywhere?'

b. Nem esik az eső| sehol/?

not falls the rain nowhere

'Isn't it raining anywhere?'

19 The availability of the on reading can additionally be tested by the insertion of indefinites like valahol 'somewhere', as in (i) below:

(i) Nem esik az eső valahol/ $\backslash$ ?

not falls the rain somewhere

'Isn't it rainining somewhere?' 

b. * Az esö is nem esik`? the rain also not falls

The /-declarative counterparts of (24ab) are shown in (26ab), respectively:
(26) a. Nem esik $\wedge \mid$ az eső sem/l?
not falls the rain neither
'It is not raining, either?'
b. $A z$ eső sem/ esik/??
the rain neither falls
'It is not raining, either?'

As the following example shows, (25a), having an on reading, does not have a \-declarative counterpart:

(27) /-declarative with an on reading:
a. * Nem esik $\wedge$ az eső is $/$ ?
not falls the rain also
'Isn't it raining, too?'

Note that the string in (27a) is not ungrammatical as a declarative, but, as discussed in fn. 17 above, it has very specific restrictions on its uses, which seems to be incompatible with the general interpretational features of $\Lambda$ declaratives. We leave discussion of the matter for a later occasion. The lack of an (ON) reading for (27a) is already expected on the assumption that the $\mathrm{IN} / \mathrm{ON}$ ambiguity only plays a role in the case of interrogatives. ${ }^{20}$

Let us now turn to negative $-e$-interrogatives. $(28)-(29)$ show the result of inserting $-e$ into the strings in $(24)-(25)$ :

(28) $-e$-interrogatives with an IN reading:
a. * Nem esik-e $\mid$ az esö sem?

not falls-E the rain either
20 The lack of on readings for rising declaratives is accounted for in Krifka (2017), which, however, relies crucially on surface syntactic differences between English rising declara- tives and ordinary polar interrogatives, absent in Hungarian.



b. *Az eső sem esik-e? the rain neither falls-E

(29) -e-interrogative with an on reading:

Nem esik-e az eső is?

not rains-E the rain also

'Isn't it raining, too?'

As the grammaticality contrast between (28) and (29) illustrates, negative $-e$ interrogatives are incompatible with sem 'neither', which was taken to be a diagnistic for the IN reading. Thus, they can only have an on reading. The contrast will be accounted for in the Appendix.

As mentioned above, there is a rich literature on the differences between the interpretations of negative and positive polar interrogatives in English. In what follows, discussion of the differences between negative and positive interrogative form types in Hungarian will be restricted to the phenomena that I believe are essential for the understanding of the interpretational differences between $\Lambda$ - and $-e$-interrogatives. Particularly interesting in this respect are the cases where positive and negative $-e$-interrogatives differ in compatibility with particular uses. One characteristic example is shown in (30) below, where the aim of asking the question is to indirectly suggest a possibility. The positive interrogative in (30a) is incompatible with this reading, and is only interpretable as an information question. This is further demonstrated by the impossibility of inserting the pragmatic marker esetleg 'perhaps' into it, which is, however, compatible with its negative counterpart in (3ob), which does have the suggestion reading available.

(30) [Context: A is looking for his glasses. S says:]

a. Otthagytad-e a konyhában (\# esetleg)? vm.left.2sg-E the kitchen.in perhaps 'Have you left them in the kitchen (perhaps)?'

b. Nem hagytad-e ott a konyhában (esetleg)? not left.2sg-E vm the kitchen.in perhaps 'Haven't you left them in the kitchen (perhaps)?'

Negative - $e$-interrogatives are characteristically used to encode rhetorical questions, as illustrated in (31), which is interpreted as equivalent to the assertion of the positive proposition 'I am your best friend': 
(31) Nem én vagyok-e a legjobb barátod? not I be.1sg-E the best friend.your 'Aren't I your best friend?'

Additionally, negative $-e$-interrogatives can appear in invitations, like their positive counterparts. In requests, provided the verb is in the indicative form, they behave analogously to their positive counterparts, as shown in (32):

(32) [Context: s, carrying heavy luggage, wishes to ask her friend A to open the door for her, so she says the following:]

a. \# Nem nyitod-e ki az ajtót?

not open.2sg-e pfx the door.acc

b. Nem nyitod ki az ajtót $/$ ?

'Will you open the door?'

'Won't you open the door?'

c. \# Nem nyitod ki/ $\backslash$ az ajtót $\bigwedge$ ?

\# 'You are not going to open the door?'

Due to lack of space, not all of the uses mentioned above will be illustrated here. (33) presents an extended version of the table in (20) that also illustrates the compatibility of the special question types with the negative form types. In this table, the ' $\checkmark$ ' sign indicates that, modulo other factors (e.g. the propositional content of the interrogative), the form under consideration is available to express the relevant function.

(33) The expression of certain (special) question types with interrogative and /-declarative form types in Hungarian

\begin{tabular}{llllllll}
\hline & \multicolumn{3}{c}{$\boldsymbol{e}$-interrogative } & \multicolumn{2}{l}{ ハ-interrogative } & \multicolumn{2}{l}{ ハ-declarative } \\
& + & - & + & - & + & - \\
\hline \multirow{2}{*}{ Neutral information } & $\checkmark$ & $\checkmark$ & $\checkmark$ & $\checkmark$ & $\times$ & $\times$ \\
question & $(11 \mathrm{a})$, & $(42 \mathrm{a})$ & $(11 \mathrm{~b})$, & $(42 \mathrm{~b})$, & $(11 \mathrm{c})$, & $(44 \mathrm{~b})$ \\
& $(39 \mathrm{a})$ & & $(39 \mathrm{c})$ & $(44 \mathrm{a})$ & $(39 \mathrm{e})$ & \\
Grounding question & $\times$ & $\times$ & $\%$ & $\checkmark$ & $\checkmark$ & $\checkmark$ \\
& $(12 \mathrm{a})$, & $(41 \mathrm{a}-\mathrm{b})$ & $(12 \mathrm{~b})$, & $(41 \mathrm{c}-\mathrm{d})$, & $(12 \mathrm{c})$, & $(43 \mathrm{c}-\mathrm{d})$ \\
& $(38 \mathrm{a})$ & & $(38 \mathrm{c})$ & $(43 \mathrm{a}-\mathrm{b})$ & $(38 \mathrm{e})$ &
\end{tabular}




\begin{tabular}{lllllll}
\hline & \multicolumn{2}{c}{$\boldsymbol{e}$-interrogative } & \multicolumn{2}{c}{ 八-interrogative } & \multicolumn{2}{l}{ 八-declarative } \\
& + & - & + & - & + & - \\
& & & & & & \\
\hline \multirow{2}{*}{ Indirect request ${ }^{21}$} & $\times$ & $\times$ & $\checkmark$ & $\checkmark$ & $\times$ & $\times$ \\
& $(13 \mathrm{a})$ & $(32 \mathrm{a})$ & $(13 \mathrm{~b})$ & $(32 \mathrm{~b})$ & $(13 \mathrm{c})$ & $(32 \mathrm{c})$ \\
Indirect offer & $\checkmark$ & $\checkmark$ & $\checkmark$ & $\checkmark$ & $\times$ & $\times$ \\
& $(14 \mathrm{a})$ & & $(14 \mathrm{~b})$ & & $(14 \mathrm{c})$ & \\
Conversation starter & $\times$ & $\times$ & $\checkmark$ & $\times$ & $\times$ & $\times$ \\
& $(15 \mathrm{a})$ & & $(15 \mathrm{~b})$ & & $(15 \mathrm{c})$ & \\
Pedagogical question & $\checkmark$ & $\times$ & $\checkmark$ & $\times$ & $\times$ & $\times$ \\
Monological question & $\checkmark$ & $\checkmark$ & $\checkmark$ & $\checkmark$ & $\times$ & $\times$ \\
Exam question & $\checkmark$ & $\times$ & $\checkmark$ & $\times$ & $\times$ & $\times$ \\
& $(18 \mathrm{a})$ & & $(18 \mathrm{~b})$ & & $(18 \mathrm{c})$ & \\
Rhetorical question & $\checkmark$ & $\checkmark$ & $\checkmark$ & $\checkmark$ & $\times$ & $\times$ \\
& $(19)$ & $(31)$ & $(64)$ & $(71)$ & & \\
\hline
\end{tabular}

The data illustrated above points to an intricate interplay between the contributions of $-e$ and nem 'not' in Hungarian. Although we are not in a position to explain all the facts, and some categories would require more detailed data collection, in the rest of the paper we will sketch an approach, based on some distinctions made in Sudo (2013), which can account for some of the differences in the availability of the various special question readings for the form types discussed above by attributing separate contributions to $-e$ and negation. It will be argued that the interpretational possibilities of interrogatives containing $-e$ and/or nem are derived from the independent contributions of these two elements. Section 3 reviews the main claims of Sudo's account.

\section{$3 \quad$ Sudo (2013) on the types of bias in polar questions}

Sudo (2013) puts forward a feature-based approach to biased polar questions, which he applies to the characterization of English and Japanese data. He proposes that the conditions determining the choice between the forms of polar interrogatives available in these languages are to be captured by recognizing two different types of bias, and shows that English polar interrogatives and

21 The judgments refer to forms containing the indicative form of the verb. 
Japanese polar interrogatives (marked either intonationally or by one of the two particles -no and -desho) show different configurations of these two biases. The first of them is referred to as evidential bias, because the speaker's preference for one of the possible answers is based on the availability of contextual evidence, discussed below. The second type of bias, referred to as a positive/negative epistemic bias, is introduced by a polar interrogative if it "carries an implication compatible with the positive (resp. negative) answer based on what the speaker believes" (Sudo, 2013: 281). Sudo (2013: 282) emphasizes that evidential bias has to do with contextual information available to all conversational participants, and thus it is inherently public, whereas epistemic bias has to do with the speaker's private beliefs, which are not necessarily shared with the other conversational participants.

The significance of Sudo's work does not lie in introducing the concepts listed above, but in synthetising previous proposals that made important claims about them individually. One source is Ladd's (1981) characterization of the contexts where negative interrogatives on their IN vs. ON readings are felicitous, discussed with respect to (1) above, according to which, in the case of the IN reading, the positive answer is "expected", and in the case of the on reading, the speaker "believes" the positive answer. The idea of systematically explaining the distribution of English positive polar questions (PPQ), and negative polar questions with an outside-negation (ON-NPQ) and an insidenegation (IN-NPQ) reading on the basis of availability of contextual evidence originates from Büring and Gunlogson (2000). These authors consider contextual evidence to be "evidence that has just become mutually available to the participants in the current discourse situation" (: 7$),{ }^{22}$ but argue that it only plays a role in the licensing of different form types of interrogatives if it is compelling. Evidence for $p$ is taken to be compelling "if, considered in isolation, it would allow the participants to assume $p$ (i.e. the evidence could reasonably be considered to justify the inference that $p$ )" and evidence against $p$ is considered compelling "if it is compelling evidence for the opposite of $p, w-p$ " (Büring and Gunlogson, 2000: 7). ${ }^{23}$ (34) below summarizes Büring and Gunlogson's (2000:

22 Büring and Gunlogson (2000: 8) emphasize the primacy of the role of recent contextual evidence over information in the common ground by showing that whenever there is a contradiction between the two, it is the former that determines whether a particular interrogative is felicitous.

23 Reese (2007: 87) provides the following definition for the same concept in an SDRT framework: "there is compelling evidence for $\varphi$ in a discourse context understood as an $\operatorname{SDRS} \tau$, just in case $\tau$ together with a set of reasonable assumptions $\Gamma$ defeasibly entails $\varphi$." 
11) views as to what types of compelling contextual evidence are compatible with different form types of English polar interrogatives, together with the abbreviations introduced by Sudo (2013) for the relevant configurations. For the sake of brevity we will use the latter from Section 4 onwards. ${ }^{24}$ The term neutral context refers to those contexts where no compelling contextual evidence is available for either of the possible answers.

(34) Evidential biases of English polar questions

\begin{tabular}{lll} 
Form type & $\begin{array}{l}\text { Context it is compatible with } \\
\text { (Büring and Gunlogson's terminology) }\end{array}$ & $\begin{array}{l}\text { Type of evidential bias } \\
\text { (Sudo's terminology) }\end{array}$ \\
\hline PPQ & $\begin{array}{l}\text { neutral context; compelling contextual } \\
\text { evidence for the positive answer }\end{array}$ & -negative \\
ON-NPQ & $\begin{array}{l}\text { neutral context; compelling contextual } \\
\text { evidence for the negative answer }\end{array}$ & -positive \\
& $\begin{array}{l}\text { compelling contextual evidence } \\
\text { fN-NPQ }\end{array}$ & +negative \\
& &
\end{tabular}

Relevant examples illustrating the appearance of the different types of questions in the various contexts will be shown in the next section, where Sudo's (2013) tests are applied to the Hungarian constructions under consideration.

Regarding epistemic biases, Sudo (2013) argues that whereas English PPQS carry none, that is, their appearance does not depend on the speaker's beliefs concerning the truth of the positive or the negative answer, negative polar interrogatives carry positive epistemic bias on both of their interpretations, that is, they can only be used if the speaker's private beliefs support the positive answer.

\footnotetext{
24 Although Sudo does not follow Büring and Gunlogson in using the term compelling to characterize contextual evidence, since he follows their judgments concerning the English examples, I will assume that whenever he talks about contextual evidence supporting an answer, he means compelling contextual evidence.

25 Note that Krifka (2017) considers IN-NPQS to be compatible with a neutral context.
} 
(35) Epistemic biases of English polar questions on Sudo's account

Form type Type of epistemic bias

\begin{tabular}{ll}
\hline PPQ & none \\
ON-NPQ & positive \\
IN-NPQ & positive \\
\hline
\end{tabular}

SUDO, 2013: 284, (19)

Sudo (2013: 282) notes that the epistemic bias is not always relative to the speaker's belief per se, arguing that "there are $\mathrm{ON}-\mathrm{NPQS}$ that imply a positive expectation stemming from the norm/rules (deontic) or what the speaker desires (bouletic), rather than what the speaker believes to be true", whereas the bias of IN-NPQS is always epistemic. ${ }^{26}$

Sudo (2013) compares the bias types associated with English polar interrogatives to those associated with three Japanese ones, one marked purely intonationally, and two containing the question particles -no and -desho. $\left(3^{6}\right)^{27}$ shows the judgments of the author concerning the first construction above, which, as will be shown below, seems to behave in a manner very similar to Hungarian -e-interrogatives. For example, as opposed to their English counterparts, the Japanese positive interrogatives under consideration are only licensed "in the absence of contextual evidence for either of the answers" (Sudo, 2013: 286).

26 In what follows, I will ignore this distinction. Interestingly, Sudo's view on what distinguishes between the two readings is exactly the opposite of what was proposed by Reese (2007), who also argues for a differentiation between biases coming from different sources. Reese's (2007) proposal differs significantly from Sudo's in a further respect as well, since he distinguishes between the status of the positive bias in the case of the two NPQs: for IN-NPQS, the positive proposition is assumed to be implicated, whereas in the case of ON-NPQS, it is entailed, thus, assumed to be (weakly) asserted. The reason why I am not adopting this approach is that I do not believe that analyzing negative - $e$-interrogatives in Hungarian (which only have an ON-NPQ reading) as those asserting the positive proposition would be on the right track.

27 Cf. Sudo (2013: 285, ex. (21)). 
(36) Evidential biases of Japanese polar questions with intonational marking Form type Type of evidential bias

\begin{tabular}{ll}
\hline P PQ & -negative \& -positive \\
ON-NPQ & -negative \\
IN-NPQ & +negative \\
\hline
\end{tabular}

In terms of epistemic bias, Japanese interrogatives with intonational marking are claimed by Sudo (2013) to be like English polar interrogatives: negative interrogatives are only legitimate if the positive answer is supported by the speaker's beliefs, as shown in the following table. ${ }^{28}$

(37) Epistemic biases of Japanese polar questions with intonational marking on Sudo's account

\begin{tabular}{ll} 
Form type & Type of epistemic bias \\
\hline PPQ & none \\
ON-NPQ & positive \\
IN-NPQ & positive \\
\hline
\end{tabular}

In the next section we turn to the investigation of the availability of the two types of biases in Hungarian polar interrogatives.

\section{Evidential and epistemic biases in Hungarian polar interrogatives}

In this section, the tests used by Sudo (2013) will be applied to show that the bias types argued there to determine the choice between the English and Japanese interrogative form types are applicable to the Hungarian constructions under consideration as well. We consider evidential and epistemic biases separately.

28 Cf. Sudo (2013: 285, ex. (21)). 


\subsection{Evidential bias}

4.1.1 Evidential bias in positive interrogatives

We start the discussion by looking at evidential biases associated with positive - $e$-interrogatives, $/$-interrogatives, as well as with $/ \backslash$-declaratives for comparison. The context described in $\left(3^{8}\right)^{29}$ (already used in (12) above) provides compelling evidence for the positive answer to questions $(38 \mathrm{a}, \mathrm{c}, \mathrm{e})$ and for the negative answer to questions $(38 \mathrm{~b}, \mathrm{~d}, \mathrm{f})$ :

(38) [Context: s's officemate A enters the windowless room with his jacket wet. s asks:]
a. \# Esik-e az eső?
falls-E the rain
'Is it raining?'
b. \# Süt-e a nap?
shines-E the sun
\# 'Is the sun shining?'
c. \% Esik az eső/ ?
'Is it raining?'
d. \# Süt a nap/\?
\# 'Is the sun shining?'
e. Esik/\az eső/\?
'It is raining?'
f. \# Süt/\ a nap/ $\backslash$ ?
\# 'The sun is shining?'

Thus, in a context with compelling evidence for a proposition $p$ only / $\backslash$-declaratives with propositional content $p$ are acceptable in Hungarian without any restriction. $\bigwedge$-interrogatives with the same propositional content are only acceptable for a subset of the speakers.

(39) illustrates the compatibility of the above forms with contexts where no compelling evidence for the truth of either of the answers is provided. (Cf. (11) above for a discussion of a subset of the cases.)

29 First discussed in Büring and Gunlogson (2000: 6-7). 
(39) [Context: A and s talk long-distance on the phone. s wants to know what the weather is like at A's place and asks:]

a. Esik-e az eső?

'Is it raining?'

b. Süt-e a nap?

'Is the sun shining?'

c. Esik az esö/\?

'Is it raining?'

d. Süt a nap/\?

'Is the sun shining?'

e. \# Esik/\az eső/\?

\# 'It is raining?'

f. \# Süt/\a nap/ ?

\# 'The sun is shining?'

The examples in the above list indicate that both types of positive interrogatives are compatible with a neutral context. The following table summarizes the properties of positive polar interrogatives and $/ \backslash$-declaratives in Hungarian with respect to compatibility with contextual evidence:

(40) Evidential biases of Hungarian positive polar interrogatives and / $\backslash$-declaratives

\section{Form type Type of evidential bias}

$\begin{array}{ll}\text {-e-interrogative } & \text {-negative \& -positive } \\ \text { \-interrogative } & \begin{array}{l}\text {-negative \& -positive } \\ \% \text {-negative }\end{array} \\ & \\ \text { \-declarative } & + \text { positive }\end{array}$

As (40) illustrates, positive - $e$-interrogatives behave similarly to the intonationally marked Japanese interrogatives discussed by Sudo, as in (36) above, 
and so do $/$-interrogatives for some of the speakers. For other speakers, $/$ interrogatives display properties analogous to those of English positive polar interrogatives, cf. (34) above. /-declaratives are only compatible with compelling evidence for the positive answer. It seems reasonable to assume that the fact that not all speakers accept (38c) in a context where compelling evidence is present for the positive answer is due to the latter form being blocked by a minimally different form, the $/$-declarative. ${ }^{30}$ In any case, since the behaviour of the two interrogative forms is analogous in the face of different types of contextual evidence, the fact that they are compatible with a different range of special question interpretations, discussed above, indicates that the differences in question cannot be based on the availability of contextual evidence alone.

4.1.2 Evidential bias in negative interrogatives

Next, we turn to negative interrogatives. ON readings were shown in Section 2.2 to be only available for $-e$ - and $/$ - interrogatives. The context in (41), a slightly altered version of the one in Sudo's example (2013: 280, ex. (9)) provides evidence for one of the possible answers to all the questions listed: ${ }^{31}$

(41) [Context: For a psychological experiment, we are looking for some lefthanded subjects. We have asked some of our friends, but only Mary was left-handed so far. To my surprise, János is using a pencil with his left hand, which I take to be evidence for his being left-handed, so I ask the following:]
a. \# Nem balkezes-e János is? not left-handed-E János too
\# 'Isn't John left-handed too?'
b. \# Nem jobbkezes-e János is? not right-handed-e János too 'Isn't John right-handed too?'

\footnotetext{
30 The contrast between the behaviour of Hungarian positive / /-interrogatives vs. / -declaratives and English ordinary interrogatives vs. rising declaratives illustrated above needs further investigation.

31 The context is created to be so that the presuppositions of the additive particle is are satisfied for all questions. The judgments on the translations correspond to Sudo's judgments on the same English sentences.
} 


\section{c. \# Nem balkezes János is $\wedge$ ? \\ \# 'Isn't John left-handed too?' \\ d. Nem jobbkezes János is $/$ ? \\ 'Isn't John right-handed too?'}

As the data indicate, negative - $e$-interrogatives are not compatible with a context that is biased towards any of the answers, and negative / -interrogatives can be used when the context is biased towards the negative answer, as in (41d), but not when it is biased towards the positive one, as in (41c). As a comparison of (41) with (36) illustrates, the distribution of negative $-e$-interrogatives differs from that of intonationally marked Japanese negative polar interrogatives, which are claimed to be compatible with a context supporting the positive answer. ${ }^{32}$

In (42), fashioned after Sudo (2013:280, ex. (10)), compatibility of the two kinds of interrogatives with a context that does not provide evidence for any of the possible answers to the relevant questions is illustrated:

32 Sudo claims that Japanese negative interrogatives with prosodic marking are acceptable in contexts where evidence for the positive answer is present, which he illustrates with the following example:

i) Positive Context

A: (Looking at a guidebook) There are all sorts of restaurants around here.

в: doko-ka nihon-shoku nai?

where-ka Japanese-food not.exist

'Isn't there some Japanese restaurant?'

SUDO, 2013: 298, ex. (23c)

ii) shows the Hungarian counterpart of i), which I consider to be infelicitous:

ii) Positive Context

A: (Looking at a guidebook) There are all sorts of restaurants around here.

в: \# Nincs-e valamilyen japán étterem?

be.neg-E some.kind Japanese restaurant

'Isn't there some Japanese restaurant?'

Naturally, B's reply in ii) above can be interpreted ironically, as could probably most of the examples marked with '\#’ in this paper. 
(42) [Context: We've just learned that Mary is left-handed, and are wondering who else is. I think John, who is not here, is probably left-handed too, but I am not sure. I ask: $]^{33}$

a. Nem balkezes-e János is?

'Isn't John left-handed too?'

b. Nem balkezes János is $\bigwedge$ ?

'Isn't John left-handed too?'

The above examples thus show that the behaviour of Hungarian negative $\bigwedge$-interrogatives on their on reading is analogous to that of their English counterparts: they are only incompatible with contexts providing evidence for the positive answer. Negative - $e$-interrogatives on their on reading pattern with their positive counterparts regarding evidential bias. We turn now to IN readings.

As pointed out above, of the three forms under discussion, only negative $/$-interrogatives and $/ \backslash$-declaratives have IN readings. (43) illustrates a context where evidence for one of the possible answers to all the questions in (43a-d) is present, a slightly modified version of Sudo (2013: 285, ex. (16)):

(43) [Context: For a psychological experiment, we are looking for some lefthanded subjects. Bill is right-handed and Mary is left-handed. We're wondering who else is left-handed. John is using a pen with his right hand in front of us, which I take to be evidence for his being right-handed, so I ask the following.]

a. \# János sem jobbkezes/l?

János neither right-handed

'Isn't John right-handed either?'

b. János sem balkezes/?

János neither left-handed

'Isn't John left-handed either?'

c. \# János sem/ $/$ jobbkezes $/$ ?

'John isn't right-handed either?'

As noted by Sudo (2013: 280), the other two questions discussed in (41) above would not be compatible with the speaker's expectation for the positive answer. He considers this type of expectation to represent the epistemic bias, discussed below. 


\section{d. János sem/ $\backslash$ balkezes $/$ ? 'John isn't left-handed either?'}

The data above indicate that both $/$-interrogatives and $/$-declaratives can be used in the presence of contextual evidence for the negative answer but not in the presence of evidence for the positive one. (44) places these forms in a context where no evidence for any of the answers is present, a slightly modified version of Sudo (2013: 285, ex. (17)):

(44) [Context: Bill is right-handed and Mary is left-handed. We're wondering who else is left-handed. I think that I have seen John, who is not around right now, use a pen with his right hand, and therefore ask the following:]

a. \# János sem balkezes $\wedge$ ?

\# 'Isn't John left-handed either?'

b. \# János sem/ $/$ balkezes/ $\backslash$ ?

\# 'Isn't John left-handed either?'

The examples show that negative / -interrogatives and /-declaratives with an IN reading in Hungarian are incompatible with the lack of compelling evidence for any of the answers.

The results of the tests on the evidential biases associated with Hungarian negative questions are summarized below:

(45) Evidential biases of Hungarian negative polar interrogatives and /-declaratives

\begin{tabular}{lll} 
Form type & & Type of evidential bias \\
\hline - $e$-interrogative & ON & -negative \& -positive \\
\-interrogative & ON & -positive \\
& IN & +negative \\
& & \\
\-declarative & IN & +negative \\
\hline
\end{tabular}

Comparing the tables in (40) and (45) the following generalizations can be made: 
(46) i) /-declaratives are only compatible with contexts where there is compelling contextual evidence for the answer that corresponds to the propositional content of the declarative.

ii) Positive and negative - $e$-interrogatives are both only compatible with neutral contexts.

iii) Positive / -interrogatives are only compatible with the neutral context for one group of speakers, but for another group of speakers they are also compatible with compelling contextual evidence for the positive answer (and thus behave analogously to positive polar interrogatives in English).

iv) Negative $/$-interrogatives are incompatible with evidence for the positive answer. Compatibility with a neutral context correlates with the IN/ON distinction (as observed for English, too).

Fact (46i) parallels the observations made in the literature regarding English rising declaratives, and will not be investigated here any further. The difference between - $e$ - and $/ \backslash$-interrogatives with respect to compatibility with neutral contexts, described in (46ii-iv), will be accounted for in Section 5 , together with the differences between the availability of the two form types for the expression of certain special question meanings, discussed in Section 2. The difference between IN / on readings of negative $/ /$-interrogatives with respect to compatibility with the neutral context, described in (46iv), will be addressed in Section 6. (46ii-iv) also show that none of the interrogative forms is compatible with evidence for the answer whose propositional content is the opposite of that of the interrogative, as observed for English by Büring and Gunlogson (2000). Given that the phenomenon is not specific to Hungarian, we will refrain from discussing it any further here. ${ }^{34}$ Next, we turn to the investigation of epistemic bias in negative questions.

34 Krifka (2017) proposes an account of the relevant English data in the framework of Cohen and Krifka (2011), where speech acts are analyzed as transitions between commitment spaces (sets of commitment states). He claims that positive polar interrogatives are ambiguous between two interpretations, one on which they denote question acts, thus proposing two continuations for the addressee that are presented as equal, and one on which they propose one preferred continuation (which, however, can also be rejected by the interlocutor). IN-NPQS are unambiguously associated with the latter type of interpretation, proposing the assertion of a negative 'sentence radical', whereas ON-NPQS are requests to denegate (i.e. refrain from asserting) a positive proposition. It is assumed by Krifka that whenever the context supports one of the answers, only forms presenting 


\subsection{Epistemic bias}

Sudo (2013) claims that PPQs in English do not show any epistemic bias, but their negative counterparts with 'high negation' are biased towards the positive answer on all their readings, which he considers proven by the contrast between (47a) and (47b) (cf. Sudo 2013: 283, ex. (12)):

(47) [Context: You told me that you went to a party yesterday. I have absolutely no idea who else did (or was supposed to go). I ask:]

a. Did (perhaps) John go to the party too?

b. \# Didn't (perhaps) John go to the party too?

(48ab) show that the Hungarian positive polar interrogatives are compatible with the same context, whereas the two negative forms with an oN reading, in (48cd), are not.

(48) [Context: You told me that you went to a party yesterday. I have absolutely no idea who else did (or was supposed to go). I ask:]

a. Ott volt-e (esetleg) János is a buliban?

there was-E perhaps John too the party.in

'Did (perhaps) John go to the party too?'

b. Ott volt (esetleg) János is a buliban $\bigwedge$ ?

'Did (perhaps) John go to the party too?'

only one continuation are possible, where the proposition proposed corresponds to the evidence (in the case of positive interrogatives), or the proposition dispreferred contradicts it (in the case of ON-NPQS). In addition to lacking enough distinctions that could be used for differentiating between on readings of $/$ - and - $e$-interrogatives in Hungarian, the approach also fails to offer different formalizations of IN-NPQS and negative rising declaratives cross-linguistically. Trinh (2014) accounts for the phenomena in English by postulating a null morpheme $E$ that triggers the presupposition that there is evidence for the truth of the proposition the question is based on. Trinh denies that there is a distinction between IN/oN readings, thus, his account predicts that negative interrogatives all behave alike in the face of different kinds of contextual evidence. I believe that previous evidence for English convincingly argue against this claim, and the data presented above for Hungarian also contradict it. The proposal that I find most convincing in this respect is due to Farkas and Bruce (2010), according to whom reversing answers (whose propositional content is the opposite of that of the polar question) are more marked than confirming answers, thus, preference goes for the latter. 
c. \# Nem volt-e ott (esetleg) János is a buliban? not was-E there perhaps John too the party.in

\# 'Didn't (perhaps) John go to the party too?'

d. \# Nem volt ott (esetleg) János is a buliban/ $\$ ?

\# 'Didn't (perhaps) John go to the party too?'

I believe that in order to prove that $(47 \mathrm{~b})$ and $(48 \mathrm{c}, \mathrm{d})$ have a positive epistemic bias it also has to be shown that they are acceptable in the context shown in (49) but unacceptable in the one shown in (50), which is exactly what we observe:

(49) [Context: You have just told me about Mary's birthday party you went to. I have absolutely no idea who else went (or was supposed to go). I know that John is a good friend of Mary's, and ask:]

a. Ott volt-e (esetleg)János is a buliban?

'Did (perhaps) John go to the party too?'

b. Ott volt (esetleg) János is a buliban/

'Did (perhaps) John go to the party too?'

c. Nem volt-e ott (esetleg)János is a buliban?

'Didn't (perhaps) John go to the party too?'

d. Nem volt ott (esetleg) János is a buliban $\bigwedge$ ?

'Didn't (perhaps) John go to the party too?'

(50) [Context: You have just told me about Mary's birthday party you went to. I have absolutely no idea who else went (or was supposed to go). I know that John and Mary hate each other, and ask: ${ }^{35}$

a. Ott volt-e (esetleg)János is a buliban?

'Did (perhaps) John go to the party too?'

b. Ott volt (esetleg) János is a buliban/ $/$ ?

'Did (perhaps) John go to the party too?'

35 Note that in a context where the facts concerning the relationship between John and Mary are assumed to be part of the common ground, and not just privately known by the speaker, $\left(5^{\circ} \mathrm{a}, \mathrm{b}\right)$ would be inappropriate, too. 
c. \# Nem volt-e ott (esetleg) János is a buliban?

\# 'Didn't (perhaps) John go to the party too?'

d. \# Nem volt ott (esetleg) János is a buliban/।?

'Didn't (perhaps) John go to the party too?'

The next three examples test the epistemic bias of IN readings of / $/$-interrogatives:

(51) [Context: You told me that Bill did not go to the party yesterday that you went to. I have absolutely no idea who else went there (or was supposed to go). I ask:]

a. \# János sem volt ott (esetleg) a buliban/\? János neither was there perhaps the party.in \# 'Didn't John go to the party either?'

(52) [Context: You told me that Bill did not go to Mary's birthday party that you went to. I have absolutely no idea who else went (or was supposed to go). I know that John is a good friend of Mary's, and ask:]

a. János sem volt ott (esetleg) a buliban/ $\backslash$ ?

'Didn't John go to the party either?'

(53) [Context: You told me that Bill did not go to Mary's birthday party you went to. I have absolutely no idea who else went (or was supposed to go). I know that John and Mary hate each other, and ask:]

a. \# János sem volt ott (esetleg) a buliban/ ?

\# 'Didn't John go to the party either?'

The following table summarizes the results of the above tests, according to which all $\mathrm{ON}$ and IN readings of Hungarian negative polar interrogatives show positive epistemic bias. (Positive polar interrogatives, showing no epistemic bias, are left out.) 
(54) Epistemic biases of Hungarian negative polar interrogatives and $/$-declaratives in contexts lacking evidence for any of the answers

\begin{tabular}{lll} 
Form type & & Type of epistemic bias \\
\hline$-e$-interrogative & ON & positive \\
& & \\
M-interrogative & ON & positive \\
& IN & positive \\
\hline
\end{tabular}

In the following sections, I will investigate how the facts observed about the biases associated with the two types of polar interrogatives in Hungarian, as well as the availability of the various special question interpretations can be accounted for in formally more explicit terms. Section 5 deals with the interpretation of the interrogative marker $-e$, in Section 6 the contribution of nem 'not' is discussed.

\section{The interpretation of $-e$ : a proposal}

In this section I will consider how the distinction between the bias properties of the two basic Hungarian interrogative form types discussed above can be used to explain the contrasts observed with respect to their availability in particular contexts in Section 2 (cf. (33)). It will be proposed that $-e$ introduces a condition on felicitous contexts of utterance that is incompatible with some of the special question interpretations. Following Davis (2009) and Trinh (2014), this condition will be referred to as a contextual presupposition. ${ }^{36}$ After illustrating how the proposal accounts for two examples discussed above, we will turn to data that appear more challenging at first sight, and show how they lend themselves to a similar analysis.

The findings in Section 4.1 concerning the compatibility of - $e$-interrogatives with contextual evidence lead to defining the conditions on the use of this construction as follows:

$36 \quad$ Discussion of the issue of whether this condition could be classified as use-conditional meaning along the lines proposed in Gutzmann (2015) will be left for another occasion. 
(55) Presupposition of $-e$-interrogatives with propositional content $p$ (first version)

There is no compelling contextual evidence for either of the possible answers to the question.

I assume that evidence available in a context $C$ can be represented as a set of propositions $E v(C)$, and I follow Reese (2007: 87) in saying that the presence of compelling evidence for a proposition $p$ is to be modelled by saying that the context, supplemented by a set of reasonable assumptions $\Gamma$ (also modelled as a set of propositions) defeasibly (non-monotonically) entails $p$ (cf. fn. 23 above). Consequently, (55) can be presented more formally as follows: ${ }^{37}$

(56) Presupposition of -e-interrogatives with propositional content $p$ (second version)

$E v(C) \cup \Gamma \not<p, E v(C) \cup \Gamma \mid \propto \neg p$

Let us consider whether (56) can account for the relevant data. (12a) above, repeated in (57a) below, shows that $-e$-interrogatives cannot encode grounding questions:

(57) [Context:s's officemate A enters the windowless room with his jacket wet. s asks:]

a. \# Esik-e az eső?

'Is it raining?'

(56) correctly accounts for the prohibition against the use of $-e$ in (57a): the jacket being wet, together with some reasonable assumptions, can be assumed to entail nonmonotonically that it is raining outside.

Consider now the case of questions asked in formal settings, which have legal consequences, illustrated in (16ab) above, repeated in (58ab):

(58) [Context: At a trial, the judge asks the witness:]

a. Ismeri-e a vádlottat?

know.3sg-E the defendant.acc

'Do you know the defendant?'

37 ' $x$ ' stands for lack of non-monotonic entailment. 


\section{b. \# Ismeri a vádlottat/\?}

'Do you know the defendant?'

In the context above, the witness has to bear the legal consequences of his reply. Thus, the judge wants to avoid giving the impression that one of the answers is supported by available evidence, because this might influence the witness. Since $(58 \mathrm{~b})$ is compatible with evidence supporting the positive answer, and thus does not exclude the unwanted assumption, it is blocked in the context under consideration, leaving (58a) as the only available form.

Let us now turn to the less obvious cases. (15ab) above, repeated in (59ab), illustrate that the two forms are not equally availabilable to ask a question in order to start a conversation:

(59) [Context: Students A and s, who do not know each other, are waiting outside the auditorium to go to the same evening lecture. $\mathrm{s}$ wants to initiate a conversation with A, and therefore asks:]

a. \# Elsóéves vagy-e?

first.year be.2sg-E

'Are you a first year student?'

b. Első́ves vagy/।?

'Are you a first year student?'

In the context described above, neither of the possible answers to (59a) or (59b) seem to be supported by the evidence available, thus there seems to be no reason why the former should be considered infelicitous, given the proposal in (56). I propose the following explanation. Whenever a speaker initiates a conversation by asking a question of the addressee, she is not primarily interested in gathering information, but in signalling friendliness and suggesting that they have common topics that they could lead an interesting conversation about. If the interlocutors don't know each other, such common topics can only be related to evidence in the context (available to both participants). Use of the -e-interrogative in a conversation between strangers explicitly conveys that the answer to the question is not based on contextual evidence, and thus that the questioner's aim is to collect some information she is missing. Given, however, that the /-interrogative is compatible with evidence supporting the positive answer, it can be used to create the impression that the question is asked in order to check some assumption based on contextual evidence, in other words, that it is intended as a grounding question. For example, in the hypothetical situation described in (59), the questioner pretends with the use 
of the $/$-interrogative that evidence in the context supports the assumption that the addressee is a first year student, which can be confirmed or rejected by the addressee, thus providing an opportunity to continue the conversation.

Let us now turn to indirect requests, whose non-conventionalized forms were argued to be incompatible with the $-e$-interrogative. (13ab) above are repeated in (6oab):

(6o) [Context: s, carrying heavy luggage, wishes to ask her friend A to open the door for her, so she says the following:]

a. \# Kinyitod-e az ajtót?

pfx.open.2sg-E the door.acc

\# 'Are you going to open the door?'

b. Kinyitod az ajtót $\wedge$ ?

'Will you open the door?'

According to Searle (1979: 6o-61), "[i]n indirect speech acts the speaker communicates to the hearer more than he actually says by way of relying on their mutually shared background information, both linguistic and nonlinguistic, together with the general powers of rationality and inference on the part of the hearer". Using the terminology introduced above, these claims can be reformulated by saying that the speaker's intention that her utterance be taken as a request depends on taking contextual evidence, certain reasonable assumptions, as well as information in the common ground (i.e. publicly available information not necessarily in the context) into account. In the situation under consideration, (6oa) asks whether the addressee is planning to open the door in the near future. If we assume that - $e$ is unavailable when the answer is nonmonotonically entailed by contextual evidence (in the current situation, the speaker carrying heavy luggage and not being able to open the door alone) and cultural conventions (in the common ground), and understanding the interrogative as a request depends on these factors, plus certain reasonable assumptions, it follows that (6oa) is not available for serving the purpose of requesting. (61) shows how (56) is minimally extended to predict that not only contextual evicence but also information from the common ground is taken into consideration in the course of accounting for the appearance of $-e:^{38}$

38 It is assumed, however, that a polar question whose propositional content is entailed by the common ground alone is infelicitous. 
(61) Presupposition of $-e$-interrogatives with propositional content $p$ (final version, formal)

$$
E v(C) \cup c G \cup \Gamma \nmid p, E v(C) \cup c G \cup \Gamma \nmid \sim \neg p
$$

(61) states that - $e$-interrogatives presuppose that neither of their possible answers follows nonmonotonically from the union of the common ground, contextual evidence, and some additional background assumptions.

The assumption that - $e$-interrogatives introduce the presupposition described in (61) above is compatible with the fact that among the special question types, exam questions, pedagogical questions and monological questions are appropriately expressed with both $-e$ - and $/$-interrogatives. These special question types share the property that the speaker has a private belief about which of the answers is true, which would be classified in Sudo (2013)'s framework as a type of epistemic bias. However, in the course of asking these questions, the questioner pretends that neither of the possible answers follows from the "public knowledge" of the interlocutors, either because she does not want to influence the addressee in finding the answer (exam questions, pedagogical questions), or she wants to provide the answer later (monological questions). ${ }^{39}$, 40 The fact that - $e$-interrogatives are available to convey that the speaker wishes to make an offer to the addressee, as illustrated in (14) above, can be explained

39 Cf. Plunze and Zimmermann (2006: 327-328) for a discussion of exam questions, which assumes that the teacher plays the role of an 'ignoramus', and Farkas and Roelofsen (2012: $5^{2}$, fn. 40) for a treatment of quiz (exam) questions, according to which "the questioner places the conversation in a state where either answer to her question is treated as a possible addition even though it is commonly understood that she herself knows the correct answer and therefore only one possible answer is compatible with her belief state".

40 Preliminary research suggests that -e-interrogatives in embedded position also indicate lack of evidence for both of the answers, since it is impossible to construct a Hungarian complex sentence with an embedded polar interrogative that is biased towards one of its possible answers. For example, there is no way to express in Hungarian the meaning of Eckardt's (2007: 456) question The captain needs to know if you tend to get seasick, which indicates that only the positive answer is interesting and thus requested. The interpretation of i) below is identical to a variant of the English sentence above where if is replaced by whether, and requires that positive and negative answers be equally listed (Bolinger, 1978; Eckardt, 2007):

i) A kapitánynak tudnia kell, hogy hajlamos vagy-e a tengeribetegségre. the captain.dat know.inf.3sg must that liable be.2sg-E the seasickness.onto 'The captain needs to know whether you tend to get seasick.' 
by saying, following Brown and Levinson (1978), that conventionalized ways of expressing an offer "may at times be perceived to demonstrate the speaker's superiority" (Bartels, 1999:269), and therefore a form that suggests that the public knowledge of the interlocutors does not support any of the answers, and the addressee is thus free to react as he wishes is even preferred in particular cases.

The final case we consider here is that of rhetorical questions, illustrated in (19) above, repeated in (62):

(62) Csoda-e, ha az ember megbolondul? miracle-E if the person gets.mad 'Is it a miracle, if a person gets mad?' SZIKSZAINÉ NAGY, 2003:131

As already mentioned in Section 2.1 above, the view that $-e$ is responsible for the rhetorical question interpretation of (62) is not compatible with generalizations about the interpretation of this particle, formalized in (61). I propose therefore that in the case of (62) and similar examples, the rhetorical question interpretation arises indirectly. By using the $-e$-form the speaker pretends that she is asking an unbiased genuine information question, such that neither of the possible answers follows from publicly available information, but the content of the question is such that one of the possible answers (in the present case, the negative one) appears trivially true. This is recognized by the hearer, who interprets the question as a rhetorical one. ${ }^{41}$ For a proof that the rhetorical question reading of (62) is not due to $-e$ note that the $/ \wedge$-counterpart of the latter, shown in (63), is perceived to have an equally marked rhetorical question interpretation:

\section{(63) Csoda, ha az ember megbolondul $/$ ?}

'Is it a miracle, if a person gets mad?'

In the next section we turn to the discussion of the contribution of the negative particle nem to the interpretation of interrogatives.

41 This effect is often accompanied by a special prosodic marking, a multiple $/$-tone on the -e-interrogative. 
In this section we are going to look at the contribution of the negative particle nem 'not' to the interpretation of polar interrogatives in Hungarian. Negative $\bigwedge$-interrogatives were shown above to be ambiguous between an IN and an ON reading, whereas negative $-e$-interrogatives were shown to possess an ON reading only. It was also argued above that, independently of the distinction between the $O N$ and IN readings, negative interrogatives all introduce a positive epistemic bias. In what follows, a proposal will be made as to how to account for these facts, after reviewing some of the proposals in the literature that aim to account for the distinction between the ON and IN readings of English polar interrogatives with high negation, as in Isn't Jane coming?, and considering whether they would be applicable to Hungarian.

Romero and Han (2004) consider the IN/ON ambiguity to be the result of a scope ambiguity between negation and an "epistemic, conversational" operator at LF, referred to as VERUM, which is taken to assert that "the speaker is certain that $p$ should be added to the Common Ground" (:627), and is abbreviated in semantic representations as FOR-SURE-CG ${ }_{x}$. The LFS associated with (64a), having an IN reading, and with (65a), having an on reading, are shown in (64b) and (65b), respectively. Their semantic values given in terms of a set of propositions consisting of the propositional content of the interrogative itself and its negation (in that order) are shown in $(64 \mathrm{c})-(65 \mathrm{c})$ (Romero and Han, 2004: 635-637):

(64) a. Isn't Jane coming either?

b. LF: [CP $Q$ VERUM [not [ ${ }_{\mathrm{IP}}$ Jane is coming] either]]

c. $\left\{\right.$ FOR-SURE-CG $G_{x} \neg$ p, $\neg$ FOR-SURE-CG $G_{x} \neg$ P $\}$

(65) a. Isn't Jane coming too?

b. LF: [CP Q not [VERUM [IP Jane is coming] too]]]

c. $\left\{\neg\right.$ FOR-SURE-CG ${ }_{x}$ p, FOR-SURE-CG $\mathrm{x}$ p

Note, importantly, that this account attributes the negative particle in the (only) on reading of (65a) a propositional negation interpretation, as the first element of the set in $(65 \mathrm{c})$ shows. In other respects, the assumption of a genuine scope ambiguity between negation and VERUM seems to successfully discriminate between IN and on readings in English. Given that in Hungarian, negative answers to /-interrogatives can be expressed on any of their readings with the help of unambiguous declaratives that are string-identical to the interrogative and that lack the FOR-SURE mean- 
ing component, the proposal by Romero and Han (2004) does not seem to be adoptable in this language. ${ }^{42}$

Reese (2007) argues for a basic distinction between IN and ON readings of negative polar interrogatives: whereas the former express the speech act type QUESTION, the latter are associated with a conventionalized complex speech act type ASSERTION - QUESTION by the grammar (cf. Asher and Lascarides, 2001, 2003). As a result, the positive speaker biases of the two are viewed as fundamentally different: for IN readings the positive bias is an implicature, for $\mathrm{ON}$ readings it is a conventionalized indirect assertion. The distinction is supported by the tests offered by Sadock (1974) for determining the illocutionary force of utterances: whereas ON-NPQS are compatible with sentence-initial after all, and can be followed by an assertion containing the discourse marker yet, which identify assertions, IN-NPQS are not. (Both types of negative interrogatives satisfy Sadock's diagnostics for questions, however.) The application of the above strategy runs into difficulties in Hungarian though: the addition of végül is 'after all' (literally: 'finally too') to negative - $e$-interrogatives (with a single on reading) does not seem to be acceptable in all cases, as (66) (a modified version of (3ob)) shows:

(66) [Context: A is looking for his glasses. s says:]

Nem hagytad-e ott a konyhában (\#végül is)?

not left.2sg-E vm the kitchen.in finally too

'Haven't you left them in the kitchen (\#after all)?'

Krifka (2017) proposes a new interpretation for negative polar questions by saying that the contribution of the negative particle on the on reading of Isn't there a vegetarian restaurant around here? is to introduce speech act denegation (i.e. refraining from performing a speech act, cf. fn. 34 above). Informally, the above sentence is analyzed as follows: the speaker asks whether the addressee would refrain from making the assertion that there is a vegetarian restaurant around here. The speaker's preference for a positive answer is accounted for by saying that the interrogative expresses a rhetorical question: it is made easy for the hearer to reject the request and actually assert $p$. The above strategy could successfully explain the interpretations of on readings of Hungarian negative interrogatives used as indirect offers, requests, and suggestions. In these cases, the answer has to do with the addressee's wishes, disposi-

42 Reese (2007) points out a similar problem with respect to high negation polar interrogatives and the declaratives corresponding to the latter's negative answers in English. 
tions, aims, etc. For uses where the above criterion is not applicable, Krifka's explanation does not seem to work: $\left(6_{7} \mathrm{ab}\right)$ can by no means be analyzed as requesting the addressee to refrain from making an assertion that he has seen Mari.

(67) [Context: $\mathrm{s}$ is looking for Mari, therefore she turns to A:]

a. Nem láttad-e Marit véletlenül? not saw.2sg-e Mari.acc by.any.chance 'Haven't you seen Mari by any chance?'

b. Nem láttad Marit véletlenül/ $\backslash$ ? 'Haven't you seen Mari by any chance?'

Farkas and Bruce (2010) do not discuss ON readings of negative interrogatives (p. 96). ${ }^{43}$ Regarding IN readings they predict, on the basis of the assumption that "confirming answers are less marked than reversing ones" and that "polar questions involve a weak bias towards the least marked answer" (: 106), that they have a "weak bias towards the negative answer".

In the rest of this section, I wish to argue for the claim that the negative particle nem 'not' has a double function in Hungarian interrogatives. First, it indicates in all examples that the speaker's private knowledge, wishes, or expectations support the positive answer, in other words, it signals an epistemic, bouletic or deontic bias towards the positive answer, as argued by Reese (2007) and Sudo (2013), discussed above. ${ }^{44}$ Second, in a subset of the cases, referred to as IN readings here, it additionally has the same contribution as in ordinary declaratives: it signals propositional negation, that is, that the proposition asked about is a negative one. This assumption naturally leads to an explanation for the evidential bias for the negative answer in IN readings (cf. (45)) along the lines proposed by Farkas and Bruce (2010), cited above, and accords well with the fact that -e-interrogatives (compatible only with a neutral context) do not have an IN reading. If the negative particle in on readings is not interpreted as contributing propositional negation, the fact that the latter readings are compatible with neutral contexts does not appear problematic. At the

43 They argue, nevertheless, that nothing prevents the extension of their theory in a way that could account for the speaker's bias towards the positive answer in the relevant examples.

44 The nature of this contribution appears very similar to that of conventional implicatures (cf. Potts, 2005), except for the fact that it is only present in interrogatives. Alternatively, one could consider it a use-condition, along the lines of Gutzmann (2015). 
moment we do not have an answer to the related question of why on readings are incompatible with a context where evidence for the positive answer is provided.

Let us consider how the assumptions summarized above account for some special examples, discussed above. In negative - $e$-interrogatives, which only have an on reading, $-e$ and nem make two independent but not incompatible contributions: $-e$ introduces the presupposition formalized in (61), whereas nem signals the speaker's 'private' preference for the positive answer. Let us see how these assumptions can account for the uses of negative - $e$-interrogatives in two special contexts mentioned above, namely, to express suggestions and rhetorical questions. The example in (3ob), illustrating the first use, is repeated here:

(68) [Context: A is looking for his glasses. S says:]

Nem hagytad-e ott a konyhában (esetleg)?

not left.2sg-E vm the kitchen.in perhaps

'Haven't you left them in the kitchen (perhaps)?'

Whereas the use of $-e$ in (68) indicates that the speaker does not consider either of the possible answers to follow from publicly available knowledge, the use of nem conveys that she has a preference for the positive answer for some reasons based on her private knowledge, wishes, or expectations. The simultaneous occurrence of nem and - $e$ thus serves the purpose of suggesting to the hearer that the positive answer is correct, but without any implication that he should have come to the same conclusion himself (i.e., without being offensive).

Now we turn to rhetorical questions having the same structure, as in (31), repeated in (69):

(69) Nem én vagyok-e a legjobb barátod?

not I be.1sg-e the best friend.your

'Aren't I your best friend?'

As emphasized in the previous section, a structure containing $-e$ is not formally marked as a rhetorical question, thus, the observed effect arises indirectly: the speaker pretends with the use of $-e$ that the context is a neutral one, but the content of the question is such that the answer is observed as being trivially true or trivially false. One feature that distinguishes negative $-e$-interrogatives used as rhetorical questions from their positive counterparts is that due to the use of the negative particle it is indicated that the speaker's private knowledge 
supports the positive answer, thus, the utterance of the interrogative can only be taken to be equivalent to the assertion of the positive proposition. ${ }^{45}$

We turn now to rhetorical question readings of negative $/ /$-interrogatives on their on readings (compatible with a neutral context), illustrated in (70). We assume that this interpretation arises along the same lines as described for (69) above:

(70) Nem én vagyok a legjobb barátod/\?

'Aren't I your best friend?'

(70) is compatible with the context being neutral, but the negative particle indicates the speaker's preference for the positive answer, and the content of the question is such that the speaker has reason to believe that the hearer will share her view about the preferred answer. The fact that (69) and (70) can be viewed as having an equivalent interpretation constitutes a further argument against assuming that $-e$ is a marker of rhetorical questions.

Although a fully formalized account of all the example types illustrated in the paper remains a desideratum for further research, we believe that we have made an important step towards describing and analysing bias in polar interrogatives in Hungarian.

We have shown, on the basis of Hungarian data, how Sudo's (2013) distinction between epistemic and evidential bias can systematize the distinction between polar interrogatives within and across languages and lead to insightful analyses of the availability of special interpretations for interrogatives.

We have provided, for the first time, an integrated picture of the Hungarian system of polar interrogatives, tested against a wide range of question types. It was argued that many restrictions on the use of these forms can be accounted

45 The fact that - $e$-interrogatives containing nem are not obligatorily interpreted as rhetorical questions can be illustrated with the following example from the Hungarian National Corpus (http://corpus.nytud.hu/mnsz/), which was uttered by a journalist in the course of an interview, and was answered by the person interviewed:

i) Nem volt-e túlzó a rendôri jelenlét?

not was-E excessive the police presence

'Was the police presence not excessive?' 
for by attributing independent interpretations to the interrogative particle $-e$ and the negative particle nem ('not'). A fairly satisfactory initial analysis of the core properties of the latter ingredients and their interactions was arrived at, namely, that $-e$ introduces the presupposition that neither of the answers follows nonmonotonically from publicly available information, and that nem introduces a private preference for the positive answer by the speaker.

\section{References}

Abeillé, Anne, Danièle Godard, and Jean-Marie Marandin. 2014. French questioning declaratives in question. In P. Hofmeister and E. Norcliffe (eds.), The Core and the Periphery. Data-Driven Perspectives on Syntax Inspired by Ivan A. Sag. Stanford: CSLI Publications.

Asher, Nicholas and Alex Lascarides. 2001. Indirect speech acts. Synthese 128: 183-228.

Asher, Nicholas, and Alex Lascarides. 2003. Logics of Conversation. Cambridge: Cambridge University Press.

Austin, John L. 1962. How to Do Things With Words. Oxford: Clarendon Press.

Bartels, Christine. 1999. The Intonation of English Statements and Questions. A Compositional Interpretation. New York and London: Garland Publishing.

Biezma, María. 2009. Alternative vs. polar questions: The cornering effect. Proceedings of SALT 19: 37-54.

Bolinger, Dwight. 1978. Yes-no questions are not alternative questions. In H. Hiż (ed.) Questions, 87-105. Dordrecht: D. Reidel.

Brandt, Margareta, Marga Reis, Inger Rosengren and Ilse Zimmermann. 1992. Satztyp, Satzmodus und Illokution. In I. Rosengren (ed.), Satz und Illokution Band 1, 1-9o. Tübingen: Niemeyer.

Brown, Penelope and Stephen Levinson. 1987. Politeness. Cambridge: Cambridge University Press.

Büring, Daniel and Christine Gunlogson. 2000. Aren't Positive and Negative Polar Questions the Same? Unpublished manuscript, UCLA \& UCSC.

Cohen, Ariel and Manfred Krifka. 2011. Superlative quantifiers as modifiers of metaspeech acts. In The Baltic International Yearbook of Cognition, Logic and Communication. Volume 6: Formal Semantics and Pragmatics: Discourse, Context, and Models, $1-56$.

D. Mátai, Mária. 2003. Szófajtörténet. In J. Kiss and F. Pusztai (eds.), Magyar nyelvtörténet, 204-233. Budapest: Osiris Kiadó.

Davis, Christopher. 2009. Decisions, dynamics and the Japanese particle yo. Journal of Semantics 26: 329-366.

Eckardt, Regine. 2007. The syntax and pragmatics of embedded Yes/No-questions. In 
K. Schwabe and S. Winkler (eds.), On Information Structure, Meaning and Form, 447466. Amsterdam: John Benjamins.

É. Kiss, Katalin. 2002. The Syntax of Hungarian. Cambridge: Cambridge University Press. Fábricz, Károly. 1981. Az -e kérdő partikula. Magyar Nyelvőr 105: 447-451.

Farkas, Donka and Kim Bruce. 2010. On reacting to assertions and polar questions. Journal of Semantics 27: 81-118.

Gärtner, Hans-Martin and Beáta Gyuris. 2012. Pragmatic markers in Hungarian: Some introductory remarks. Acta Linguistica Hungarica 59 (4): 387-426.

Grice, Martine, D. Robert Ladd and Amalia Arvaniti. 2000. On the place of phrase accents in intonational phonology. Phonology 17: 143-185.

Groenendijk, Jeroen and Martin Stokhof. 1984. Studies on the Semantics of Questions and the Pragmatics of Answers. Ph.D. Dissertation, University of Amsterdam.

Gunlogson, Christine. 2003. True to Form. Rising and Falling Declaratives as Questions in English. New York: Routledge.

Gutzmann, Daniel. 2015. Use-Conditional Meaning. Studies in Multidimensional Semantics. Oxford: Oxford University Press.

Hamblin, Charles. 1973. Questions in Montague English. Foundations of Language 10: $41-53$.

Huddleston, Rodney and Geoffrey Pullum. 2002. The Cambridge Grammar of the English Language. Cambridge: Cambridge University Press.

Kálmán, Béla. 1963. Chestomathia Vogulica. Budapest: Tankönyvkiadó.

Kálmán, László (ed.) 2001. Magyar Leíró Nyelvtan. I. Mondattan. Budapest: TINTA Könyvkiadó.

Kálmán, László and Ádám Nádasdy. 1994. A hangsúly. In F. Kiefer (ed.), Strukturális Magyar Nyelvtan. 2. Fonológia, 393-467. Budapest: Akadémiai Kiadó.

Kenesei, István. 1992. Az alárendelt mondatok szerkezete. In F. Kiefer (ed.), Strukturális Magyar Nyelvtan. I. Mondattan, 529-714. Budapest: Akadémiai Kiadó.

Kenesei, István. 1994. Subordinate clauses. In F. Kiefer and K.É. Kiss (eds.), The Syntactic Structure of Hungarian, 275-354. New York: Academic Press.

Kornai, András, and László Kálmán. 1988. Hungarian sentence intonation. In H. van der Hust and N. Smith (eds.), Autosegmental Studies in Pitch Accent, 183-193. Dordrecht: Foris.

König, Ekkehard and Peter Siemund. 2007. Speech act distinctions in grammar. In T. Shopen (ed.), Language Typology and Syntactic Description. Vol. 1, 276-324. Cambridge: Cambridge University Press.

Krifka, Manfred. 2017. Negated polarity questions as denegations of assertions. In C. Lee, F. Kiefer, and M. Krifka (eds.), Contrastiveness in Information Structure, Alternatives and Scalar Implicatures, 359-398. Berlin: Springer.

Ladd, D. Robert. 1981. A first look at the semantics and pragmatics of negative questions and tag questions. CLS 17:164-171. 
Ladd, D. Robert. 1996. Intonational Phonology. Cambridge: Cambridge University Press. Li, Charles N. and Sandra A. Thompson. 1981. Mandarin Chinese. A Functional Reference Grammar. Berkeley, CA: University of California Press.

Lyons, John. 1977. Semantics, Vol. 2. Cambridge: Cambridge University Press.

Mády, Katalin and Ádám Szalontai. 2014. Where do questions begin?_-phrase-initial boundary tones in Hungarian polar questions. In N. Campbell, D. Gibbon and D. Hirst (eds.), Social and Linguistic Speech Prosody. Proceedings of the 7 th International Conference on Speech Prosody, 568-572. Dublin: Trinity College.

Meibauer, Jörg. 1986. Rhetorische Fragen. Tübingen: Niemeyer.

Péteri, Attila. 2011. Interrogativpartikeln und Modalpartikeln. Ihre Abgrenzung in ausgewählten europäischen Sprachen. In M. Harsányi (ed.), Germanistische Studien VIII., 93-107. Eger: Líceum Kiadó.

Péteri, Attila. 2013. Satztypen und Sprachkontrast. In J. Meibauer, M. Steinbach and H. Altmann (eds.), Satztypen des Deutschen, 874-901. Berlin: de Gruyter.

Plunze, Christian and Ede Zimmermann. 2006. On Truckenbrodt on interrogatives. Theoretical Linguistics 32: 321-333.

Poschmann, Claudia. 2008. All declarative questions are attributive? Belgian Journal of Linguistics 22:247-269.

Potts, Christopher. 2005. The Logic of Conventional Implicatures. Oxford: Oxford University Press.

Rakić, Stanimir. 1984. Serbo-Croation Yes/No-questions and speech acts. Journal of Pragmatics 8: 693-713.

Reese, Brian. 2007. Bias in Questions. Ph.D. Dissertation, University of Texas at Austin.

Romero, Maribel and Chung-hye Han. 2004. On negative Yes/No questions. Linguistics and Philosophy 27: 609-658.

Sadock, Jerry. 1974. Toward a Linguistic Theory of Speech Acts. New York: Academic Press.

Searle, John. 1969. Speech Acts. Cambridge: Cambridge University Press.

Searle, John. 1979. Expression and Meaning. Cambridge: Cambridge University Press.

Simoncsics, Péter. 2003. Egy uráli párhuzamosság: a nyenyec költői dikció ngey (ngæy) töltőeleme és a magyar -É szintaktomorféma. Nyelvtudományi Közlemények 100: 238-244.

Sudo, Yasutada. 2013. Biased polar questions in English and Japanese. In D. Gutzmann and H-M. Gärtner (eds.), Beyond Expressives. Explorations in Conventional Non-truthconditional Meaning, 277-297. Leiden: Brill.

Szabolcsi, Anna. 2002. Hungarian disjunctions and positive polarity. In I. Kenesei and P. Siptár (eds.), Approaches to Hungarian 8: Papers from the Budapest Conference, 217-239. Budapest: Akadémiai Kiadó.

Szabolcsi, Anna. 2015. What do quantifier particles do? Linguistics and Philosophy 38: 159-204. 
Szikszainé Nagy, Irma. 2003. A retorikai kérdések kérdő névmásai és partikulája. $M a-$ gyar Nyelv 99: 300-310.

Szili, Katalin. 2004. Tetté Vált Szavak. A Beszédaktusok Elmélete és Gyakorlata. Budapest: Tinta Könyvkiadó.

Tóth, Ildikó. 1999. Negative polarity item licensing in Hungarian. Acta Linguistica Hungarica 46:119-142.

Trinh, Tue. 2014. How to ask the obvious. A presuppositional account of evidential bias in English yes/no questions. In MIT Working Papers in Linguistics 71: 227-249.

Truckenbrodt, Hubert. 2004. Zur Strukturbedeutung von Interrogativsätzen. Linguistische Berichte 199: 313-350.

van Rooij, Robert and Marie Šafářová. 2003. On polar questions. In R.B. Young and Y. Zhou (eds.), Semantics and Linguistic Theory XIII, 292-309. Cornell University.

Varga, László. 2002. Intonation and Stress. Evidence from Hungarian. Basingstoke: Palgrave Macmillan.

Varga, László. 2010. Boundary tones and the lack of intermediate phrase in Hungarian (Revisiting the Hungarian calling contour). In L. Varga (ed.), The Even Yearbook, 1-27. Budapest: Department of English Linguistics, Eötvös Loránd University. 


\section{Appendix: an aside on diachrony and cross-linguistic comparisons}

The assumption that the use of $-e$ indicates that neither of the possible answers is in the set of propositions constituting the public knowledge of the participants-formalized in (61) - receives support from certain views concerning the historical development of this particle. Although the majority of Hungarian historical linguists assume that $-e$ originated as an interjection (cf. Benkö, 19671984) or as a demonstrative pronoun (cf. D. Mátai, 2003), Simoncsics (2003:240241) puts forward the claim that it is "without doubt the remainder of the Uralic negating verb stem * $e$-, which has been assumed to have died out". According to the latter author, this negating verb attaches to a previous "statement" and creates a "polar question" together with it, whose semantic structure can be symbolised as “ $+\mathrm{v}$-(in words: 'Yes or no?')". ${ }^{46}$ If this explanation is on the right track, the reason why negative $-e$-interrogatives cannot express IN readings follows: - $e$-interrogatives are "hidden" alternative questions of the form $\varphi \vee \neg \varphi$, whose interpretation would not change if $\varphi$ were assumed to be equivalent to a negative proposition (i.e., $\neg p$ ). A similar idea is pursued by Szabolcsi (2015), who attributes the same semantic interpretation to $-e$-interrogatives as to canonical alternative questions. This approach, however, has to be complemented with a pragmatic theory that can account for certain contrasts in the availability of the two forms. ${ }^{47}$

46 Simoncsics argues that similar structures can be found in other Uralic languages as well, cf. the Vogul interrogative particle $-a$, which is probably related to the negative particle $a t$, e.g. sol'-a? 'Is it true?' (Kálmán, 1963: 38).

47 Example i) below has the structure of a canonical alternative question. As opposed to its counterpart containing $-e$ in $(5 \mathrm{a})$, it is not appropriate in a neutral context, or as a discourse-initial assertion:

\section{i) Esik az eső vagy nem? \\ falls the rain or not \\ 'Is it raining or not?'}

I believe that there are two types of contexts where i) seems to be licensed, both of which satisfy the criterion proposed by Bolinger (1978: 89), according to which alternative questions are inappropriate in contexts where there has been no prior discussion about the relevant issue. Preliminary observations suggest that Hungarian alternative questions containing the disjunction vagy 'or' either require a context where the question has been asked before in the conversation (in a different form) but has remained unanswered, or where there is compelling evidence for both of the possible answers in the Common Ground and in the context, respectively, and thus the question is asked in order to clarify this apparent contradiction. 
The conditions on the felicitous use of Hungarian -e-interrogatives show interesting parallels to those of Chinese A-not-A questions, a type of disjunctive question that "consists of an affirmative sentence followed by its negative counterpart" (Li and Thompson, 1981: 532). According to Li and Thompson (1981)'s characterization, A-not-A questions can only be used in neutral contexts, those "in which the questioner has no assumptions concerning the proposition that is being questioned and wishes to know whether it is true" (: 550). A further investigation of the similarities between the relevant Hungarian and Chinese sentence types will be left for a later occasion. 